\title{
PENGGUNAAN MEDIA PUISI DAN PENDEKATAN SAVI UNTUK MENINGKATKAN KEMAMPUAN MENULIS CERPEN SISWA KELAS VI SEKOLAH DASAR
}

\author{
Cerianing Putri Pratiwi
}

\author{
Prodi PGSD FIP IKIP PGRI MADIUN \\ cerianingp@yahoo.com
}

\begin{abstract}
This study aims to improve quality of learning process through using write short and improve students' ability through to write short stories using poetry media and SAVI approach. Subjects in this study is students of class VI SDN Tanjung 3. Research object of learning to write short stories in Indonesian Language. Data collection techniques used in this study consist of (a) observation, (b)interview, (c)study of document, (d)questionnaire, (e)tasks. Testing the validity of data is done by triangulation. Approaches of analysing data which used in this research are descriptive qualitative and descriptive comparative. The conclusions of this research can be known that the media of poetry and SAVI approach can improve quality in learning process and ability to write short stories in Class VI SDN Tanjung 3. From the results of the pre-action learning process is still less than optimal and the average ability to write short stories 65.8. The first cycle, which is when the learning process students are more enthusiastic and average ability to write is 75.5. In second cycle, the quality of learning process has more increased. The average student's ability to write short stories was increased until 82.8.
\end{abstract}

Keywords: writing short stories, SAVI approach, poetry media

\begin{abstract}
Abstrak
Penelitian ini bertujuan untuk meningkatkan kualitas proses pembelajaran menulis cepen dan meningkatkan kemampuan menulis cerpen siswa melalui penggunaan media puisi dan pendekatan SAVI. Penelitian ini merupakan penelitian tindakan kelas. Subjek penelitian adalah siswa kelas VI SDN Tanjung 3. Objek penelitian yaitu pembelajaran menulis cerpen mata pelajaran Bahasa Indonesia. Teknik pengumpulan data yang digunakan pada penelitian ini terdiri dari (a) observasi, (b) wawancara, (c) kajian dokumen, (d) angket, (e) tugas. Pengujian validitas data dilakukan dengan cara trianggulasi. Pendekatan analisis data yang digunakan adalah deskriptif kualitatif dan deskriptif komparatif. Simpulan dari penelitian ini diketahui bahwa media puisi dan pendekatan SAVI mampu meningkatkan kualitas proses pembelajaran dan kemampuan menulis cerpen siswa kelas VI SDN Tanjung 3. Dari hasil pra tindakan proses pembelajaran masih kurang optimal dan rata-rata kemampuan menulis cerpen 65,8. Pada siklus I, proses pembelajaran siswa lebih antusias dan rata-rata kemampuan menulis menjadi 75,5. Pada siklus II, kualitas proses pembelajaran mengalami peningkatan. Ratarata kemampuan siswa dalam menulis cerpen pun meningkat menjadi 82,8 .
\end{abstract}

Kata Kunci: menulis cerpen, pendekatan SAVI, media puisi 


\section{A. Pendahuluan}

Menulis merupakan salah satu kegiatan yang dilakukan untuk menghasilkan tulisan yang diciptakan dari bentuk pikiran, angan-angan, perasaan seseorang. Dengan menulis seorang dapat menuangkan ide atau pikiran dalam bentuk tulisan secara kreatif untuk memberikan informasi yang bermanfaat bagi diri sendiri dan juga orang lain.

$\begin{array}{lll}\text { Pada } & \text { dasarnnya, orang } \\ \text { menulis } & \text { karena } & \text { ingin }\end{array}$
menyampaikan gagasan, pikiran, dan perasaannya kepada orang lain dalam bentuk tulisan. Melalui tulisan yang baik dan dengan menggunakan kata-kata yang menarik serta mudah dimengerti, akan membuat orang yang membaca tulisan tersebut dapat terpikat sehingga sependapat dengan tulisan yang telah dibuat. Oleh karena itu, keterampilan menulius haruslah dilatih sejak dini, agar menghasilkan manusia yang kreatif dalam menghasilkan sebuah tulisan. Hal itu dikarenakan sebuah keterampilan menulis tidak bisa dimiliki dengan tiba-tiba. Keteampilan menulis harus dilatih dari dini. Hal itu juga sejalan dengan pendapat Henry Guntur Tarigan (2008) bahwa menulis merupakan alat komunikasi secara tidak langsung.

Melihat pentingnya peranan menulis bagi kehidupan, maka dalam kurikulum, terdapat standar kompetensi menulis. Dengan adanyanya strandar tersebut, diharapkan semua peserta didik mampu menulis secara baik dan kreatif sehingga menghasilkan suatu produk yang bermanfaat bagi banyak kalangan. Dari SD hingga SMA terdapat standar kompetensi menulis. Hal itu menunjukkan bahwa kompetensi menulis haruslah dilatih secara terus menerus.

Menulis merupakan suatu kegiatan yang produktif dan ekspresif. Dalam kegiatan menulis, penulis haruslah terampil memanfaatkan struktur bahasa dan kosa kata. Keterampilan menulis ini tidak akan datang otomatis, tetapi harus melalui latihan yang teratur.

Pada Sekolah Dasar juga terdapat standar kompetensi menulis. Hal itu dikarena keterampilan menulis juga harus dimiliki oleh siswa SD. Pada standar kompetensi tersebut terdapat beberapa kompetensi dasar dengan tema menulis. Semua siswa diharapkan menguasai semua kompetensi dasar tersebut. Salah satu kompetensi dasar yang ada pada tingkat SD adalah menulis prosa. Salah satu jenis prosa adalah cerpen. Cepen menurut Ristri Wahyuni (2014: 120) adalah prosa baru yang menceritakan tentang sebagian kecil kehidupan pelaku utamanya yang langsung mengarah ke topik utama.

Berdasarkan hasil observasi pada pembelajaran menulis cerpen di SD Negeri Tanjung 3 Bendo Magetan, tampak banyak masalah pada pembelajaran menulis cerpen. Masalah muncul pada indikator yang dipakai guru untuk mengukur keberhasilan siswa 
masih kurang terperinci dan jelas. Hal itu menyebabkan tujuan pembelajaran masih kurang jelas sehingga siswa kurang memahami proses pembelajaran. Kedua, RPP yang dibuat oleh guru masih kurang sesuai dengan aplikasinya dalam pembelajaran. Metode pembelajaran yang dipakai oleh guru masih sederhana. Guru juga tidak menggunakan media dalam proses pembelajaran.

Selain itu, yang merupakan masalah yang paling mendasar sehingga menyebabkan timbulnya masalah-masalah lainya dalam diri siswa adalah kurangnya minat siswa terhadap pembelajaran menulis cerpen. Akibat kurang minat siswa terhadap pembelajaran menulis cerpen itu menyebabkan lemahnya konsentrasi siswa saat menulis cerpen. Permasalahan lainnya yang diketahui dari hasil wawancara dengan siswa yaitu siswa kurang mampu berpikir kreatif sehingga mengalami kesulitan dalam menulis cerpen.

Oleh karena banyaknya masalah dalam pembelajaran di SD, khususnya kelas VI pada pembelajaran menulis cerpen, maka diperlukan suatu cara untuk meningkatan kemampuan menulis cerpen. Untuk mengatasi masalah tersebut diperlukan sebuah media dan sebuah pendekatan yang tepat agar kreativitas siswa meningkat dan kemampuan menulis cerpen pun dapat meningkat.
Media puisi dan pendekatan SAVI dianggap mampu untuk mengatasi masalah yang terjadi pada pembelajaran menulis cerpen. Media dan pendekatan ini akan saling melengkapi. Media puisi adalah suatu alat yang berupa puisi, yang akan diberikan kepada siswa untuk dicari maknanya yang akan dijadikan patokan menulis cerpen. Pendekatan SAVI adalah pembelajaran yang menekankan bahwa belajar haruslah memanfaatkan semua alat indera yang dimiliki siswa. Dengan adanya media, siswa akan mampu mengembangkan kreativitasnya dalam menulis cerpen. Media puisi akan membantu siswa untuk menentukan tema, setting, plot, amanat pada cerpen yang akan dibuatnya.

Tujuan dalam penelitian ini adalah (1) meningkatkan kualitas proses pembelajaran menulis naskah cerpen melalui penggunaan media puisi dan pendekatan SAVI, (2) meningkatkan kemampuan menulis cerpen siswa melalui penggunaan media puisi dan pendekatan SAVI.

Henry Guntur Tarigan (2008:3) mengemukan bahwa menulis merupakan suatu keterampilan berbahasa yang dipergunakan untuk berkomunikasi secara tidak langsung, tidak secara tatap muka dengan orang lain. Menulis merupakan suatu kegiatan yang produktif dan ekspresif. Slamet ( 2008 : 96 ) juga mengatakan bahwa menulis merupakan kegiatan menggali pikiran dan perasaan mengenai suatu subjek, memilih hal-hal yang akan ditulis, menentukan cara menuliskannya sehingga pembaca dapat memahaminya 
dengan mudah dan jelas. Berdasarkan pendapat para ahli tersebut, menulis dapat diartikan sebagai suatu kegiatan menuangkan ide atau pikiran dalam bentuk tulisan secara kreatif untuk memberikan informasi yang bermanfaat bagi diri sendiri dan juga orang lain.

Menurut Kaswan Darmadi (1996) kemampuan menulis adalah kemampuan yang sangat kompleks. Menulis melibatkan cara berpikir dan kemampuan mengungkapkan pikiran dan gagasan serta perasaan dalam bentuk bahasa tertulis. Menulis merupakan kegiatan melahirkan pikiran dan perasaan dengan tulisan.

Jakob Sumardjo dan Saini K.M (1994:30) menyatakan bahwa cerita pendek adalah cerita berbentuk prosa yang relatif pendek. Ciri dari cerita pendek adalah cerita dengan tujuan memberikan gambaran tajam dan jelas, dalam bentuk tunggal, utuh, dan mencapai efek tunggal pula pada pembacanya. Hal ini sejalan dengan pendapat Asul Wiyanto (2005:77) yang menyatakan bahwa cerita pendek (cerpen) adalah cerita yang hanya menceritakan satu peristiwa dari seluruh kehidupan pelakunya.

Secara garis besar unsur pembangun cerpen adalah unsur instrinsik dan ekstrinsik. Burhan
Nurgiyantoro (2005: 23) menyatakan unsur instrinsik (intrinsic) adalah unsurunsur yang membangun karya sastra itu sendiri. Unsur-unsur instrinsik terdiri dari; tema, penokohan, alur, latar, dan amanat sebagai unsur yang paling menunjang dan paling dominan dalam membangun karya sastra (fiksi).

Burhan Nurgiyantoro (2005:70) menyatakan bahwa tema dapat dipandang sebagai dasar cerita, gagasan dasar umum sebuah karya novel. Menurut Herman J. Waluyo (2011:7) tema adalah gagasan pokok dalam cerita fiksi. Berpijak pada pengertian di atas, maka dapat disintesiskan tema adalah gagasan, ide, atau pikiran utama yang mendasari suatu karya sastra.

Aminudin (2002:79) berpendapat bahwa tokoh adalah pelaku yang mengembangkan peristiwa dalam cerita fiksi sehingga peristiwa itu mampu menjalin suatu peristiwa. Tokoh adalah para pelaku yang terdapat dalam sebuah fiksi (Wiyatmi, 2006:30). Berdasarkan pada beberapa pendapat di atas, maka dapat disintesiskan bahwa penokohan adalah pelukisan mengenai watak tokoh dalam cerita cerita, baik keadaan psikisnya, fisiologis, dan sosiologis tokoh. Keduanya merupakan unsur yang penting dalam sebuah cerita.

Stanton (2007:26) menyatakan alur merupakan rangkaian peristiwaperistiwa dalam sebuah cerita. Wiyatmi (2006:36) berpendapat alur atau plot adalah rangkaian peristiwa yang disusun berdasarkan hubungan kausalitas. Mengacu pada pendapat di atas, maka dapat disintesiskan bahwa alur adalah 
rangkaian cerita yang dibentuk oleh tahap-tahap peristiwa sehingga menghasilkan sebuah cerita yang indah.

Stanton

(2007:34)

berpendapat latar adalah lingkungan yang melingkupi sebuah peristiwa dalam cerita, semesta yang berinteraksi dengan peristiwa-peristiwa yang sedang berlangsung. Amanat menurut Panuti Sudjiman (1988:57) adalah sebuah ajaran moral, atau pesan yang ingin disampaikan oleh pengarang kepada pembaca. Amanat terdapat pada sebuah karya sastra secara implisit ataupun secara eksplisit

Media pembelajaran adalah suatu alat yang digunakan untuk membantu siswa dalam mengikuti pelajaran. Menurut Soenardi Bahri Djamarah dan Aswan Zain (2006: 124) berdasarkan jenisnya media dibedakan menjadi 3, media auditif, media visual. Puisi juga dapat digunakan sebagai media dalam menulis cerpen. Puisi merupakan salah satu karya sastra yang diwujudkan dengan kata-kata indah dan bermakna dalam (Ristri Wahyuni, 2014:12).

Menurut Suyatno (2009:65) SAVI adalah pembelajaran yang menekankan bahwa belajar haruslah memanfaatkan semua alat indera yang dimiliki siswa. Pendekatan SAVI yaitu belajar yang melibatkan unsur: Somatis, Auditory, Visual, dan intelektual.

\section{B. Metode Penelitian}

Penelitian ini merupakan penelitian tindakan kelas. Penelitian ini dilaksanakan di SD Negeri Tanjung 3 Bendo, Magetan. Penelitian ini berlangsung selama 5 bulan, yaitu Agustus sampai dengan Desember 2013. Rincian kegiatan penelitian tersebut adalah persiapan penelitian, koordinasi persiapan tindakan, pelaksanaan (perencanaan, tindakan, observasi, refleksi), penyusunan laporan penelitian, seminar hasil penelitian, penyempurnaan laporan berdasarkan masukan seminar.

Subjek pada penelitian ini adalah siswa kelas VI SDN Tanjung 3 Bendo, Magetan tahun ajaran 2013/2014, dengan jumlah siswa 18 , terdiri dari siswa 13 putra dan 5 siswa putri. Penelitian ini mengambil objek penelitian pembelajaran menulis cerpen mata pelajaran Bahasa dan Sastra Indonesia.

Pada penelitian ini ada dua data yaitu data verbal dan data nonverbal. Data verbal pada penelitian ini yaitu hasil rekaman kegiatan menulis cerpen siswa kelas VI SDN Tanjung 3 Bendo Magetan dengan menggunakan media puisi dan pendekatan SAVI. Data nonverbal pada penelitian ini adalah nilai hasil evaluasi kemampuan menulis cerpen siswa kelas VI SDN Tanjung 3 Bendo Magetan dengan media puisi dan pendekatan SAVI.

Pada penelitian ini sumber datanya adalah guru dan siswa. Guru bertindak sebagai informan, yaitu orang yang memberikan informasi tentang 
pembelajaran menulis cerpen di kelas VI SDN Tanjung 3 Bendo Magetan. Siswa bertindak sebagai subjek.

Teknik pengumpulan data yang digunakan pada penelitian ini terdiri dari (a) observasi, (b) wawancara, (c) kajian dokumen, (d) angket, (e) dan tugas. Pengujian validitas data dalam penelitian ini dilakukan dengan cara trianggulasi.

Metode analisis data yang yang digunakan pada penelitian ini adalah deskriptif kualitatif dan deskriptif komparatif. Analisis data deskriptif kualitatif akan digunakan untuk mengalisis data verbal, yaitu data hasil pengamatan pembelajaran menulis cerpen siswa kelas VI SDN Tanjung Bendo Magetan dengan menggunakan media puisi dan pendekatan SAVI. Analisis data deskriptif komparatif untuk data kuantitatif, yakni dengan membandingkan hasil antarsiklus.

\section{Hasil Penelitian}

Untuk mengetahui kondisi di lapangan dilakukan observasi pra tindakan melalui pengamatan, angket serta tes. Dari pengamatan yang dilakukan diketahui bahwa siswa kurang berminat mengikuti pembelajaran menulis cerpen. Guru merasa sulit membangkitkan minat siswa. Siswa belum pandai menulis cerpen. Keadaan kelas masih gaduh karena siswa kurang tetarik pada materi pembelajaran.
Guru tidak menggunakan media dan pendekatan pembelajaran. Hasil tes menulis cerpen pada pembelajaran pra tindakan belum optimal, seperti telihat pada tabel 1 .

Tabel 1. Nilai Tes Menulis Cerpen Pada Pembelajaran Pra Tindakan

\begin{tabular}{|c|c|c|c|}
\hline No. & Nilai & $\begin{array}{c}\text { Jumlah } \\
\text { Siswa }\end{array}$ & $\begin{array}{c}\text { Jumlah } \\
\text { Nilai }\end{array}$ \\
\hline 1. & 80 & 1 & 80 \\
\hline 2. & 75 & 2 & 150 \\
\hline 3. & 70 & 5 & 350 \\
\hline 4. & 65 & 3 & 195 \\
\hline 5. & 60 & 6 & 360 \\
\hline 6. & 50 & 1 & 50 \\
\hline \multicolumn{2}{|c|}{ Jumlah } & 18 & 1185 \\
\hline \multicolumn{2}{|c|}{ Rata-rata } & & 65,8 \\
\hline
\end{tabular}
kondisi pra tindakan, tedapat 1 siswa mendapat nilai 80,2 siswa mendapat nilai 75,5 siswa mendapat nilai 70,3 siswa mendapat nilai 65,6 siswa mendapat nilai 60, dan 1 siswa mendapatkan nilai 50 .

KKM pelajaran Bahasa dan Sastra Indonesia di SDN Tanjung 3, Bendo, Magetan adalah 70. Melihat KKM tersebut, maka diketahui dalam pembelajaran pada pra tindakan ini masih ada 10 siswa yang tidak tuntas. Hanya 8 siswa yang mendapatkan nilai tuntas.

\section{Siklus I}

Proses pembelajaran pada siklus I, dimulai dengan guru memberi penjelasan tujuan pembelajaran. Kemudian, guru memberikan apersepsi pada kelas tentang menulis cerpen. Apersepsi diberikan untuk menggali pengetahuan siswa. Guru membacakan 
puisi yang akan dijadikan siswa sebagai media menulis cerpen dengan pendekatan SAVI yaitu belajar harus menggunakan keempat unsur somatis, auditori, visual, dan intelektual. Setelah itu, guru membentuk kelompok. Guru memberikan beberapa puisi pada tiap kelompok. Tiap kelompok mengidentifikasi beberapa puisi yang telah diberikan. Setelah mengindentifikasi beberapa puisi ditiap kelompok, setiap siswa memilih satu puisi untuk diidentifikasi lebih mendalam. Dari puisi tersebut siswa mengidentifikasi tema dan makna puisi lalu diubah ke dalam bentuk cerpen.

Pada siklus I ini, siswa lebih antusias dalam mengikuti pembelajaran. Keadaan kelas menjadi lebih tenang. Siswa lebih berminat dalam menulis cerpen sehingga hasil tes menulis cerpen terlihat cukup bagus, seperti di bawah ini.

Tabel 2. Nilai Tes Menulis Cerpen Pada Siklus I

\begin{tabular}{cccc}
\hline No. & Nilai & $\begin{array}{c}\text { Jumlah } \\
\text { Siswa }\end{array}$ & $\begin{array}{c}\text { Jumlah } \\
\text { Nilai }\end{array}$ \\
\hline 1. & 85 & 3 & 255 \\
\hline 2. & 80 & 5 & 400 \\
\hline 3. & 75 & 4 & 300 \\
\hline 4. & 70 & 4 & 280 \\
\hline 5. & 65 & 1 & 65 \\
\hline 6. & 60 & 1 & 60 \\
\hline \multicolumn{2}{c}{ Jumlah } & 18 & 1360 \\
\hline \multicolumn{2}{c}{ Rata-rata } & & 75,5 \\
\hline \multicolumn{2}{r}{}
\end{tabular}

Melihat hasil pembelajaran pada siklus I, tedapat 3 siswa mendapat nilai 85,5 siswa mendapat nilai 80,4 siswa mendapat nilai 75,4 siswa mendapat nilai 70,1 siswa mendapat nilai 65 , dan 1 siswa mendapatkan nilai 60. Pada siklus I diketahui banyak siswa yang mendapatkan nilai tuntas dibandingkan siswa yang mendapatkan nilai tidak tuntas. Siswa yang mendapatkan nilai tuntas ada 16 siswa, sedangkan siswa yang tidak tuntas ada 2 siswa.

\section{Siklus II}

Proses pembelajaran siklus II, dilakukan setelah adanya revisi berdasarkan hasil refleksi dari siklus I. Pada siklus II, dipilihkan puisi-puisi yang digemari anak-anak. Selain itu, puisi-puisi tersebut juga ditulis secara menarik dalam kertas warna-warni agar siswa lebih antusias dan dibagikan pada tiap kelompok.

Pembelajaran dimulai dengan guru memberitahukan tujuan pembelajaran. Setelah itu, guru memberikan apersepsi. Kelas telihat tenang dan siswa tampak antusias dalam mengikuti pembelajaran. Setelah memberikan apersepsi, guru membacakan puisi. Siswa disuruh membentuk kelompok dan tiap kelompok diberi beberapa puisi. Kemudian siswa memilih satu puisi untuk diidentifikasi lebih mendalam. Setelah itu, siswa menulis cerpen berdasarkan puisi yang telah diamati. Berikut ini hasil tes menulis cerpen 
siswa kelas VI SDN Tanjung 3 pada siklus II.

Tabel 3. Nilai Tes Menulis Cerpen Pada Siklus II

\begin{tabular}{cccc}
\hline No. & Nilai & $\begin{array}{c}\text { Jumlah } \\
\text { Siswa }\end{array}$ & $\begin{array}{c}\text { Jumlah } \\
\text { Nilai }\end{array}$ \\
\hline 1. & 90 & 4 & 360 \\
\hline 2. & 85 & 6 & 510 \\
\hline 3. & 80 & 4 & 320 \\
\hline 4. & 75 & 4 & 300 \\
\hline Jumlah & 18 & 1490 \\
\hline \multicolumn{2}{r}{ Rata-rata } & & 82,8 \\
\hline
\end{tabular}

Melihat hasil tes menulis cerpen pada siklus II, diketahui bahwa semua siswa mendapatkan nilai tuntas. Tidak ada siswa yang mendapatkan nilai di bawah KKM. Nilai siswa pun cukup memuaskan yaitu ada 4 anak yang mendapatkan nilai 90. Ada 6 anak yang mendapatkan nilai 85 . Ada 4 anak yang mendapatkan nilai 80 . Ada 4 anak yang mendapakan nilai 74. Nilai rata-rata kelas mencapai 82,8 .

\section{Pembahasan}

Pada proses pembelajaran pra tindakan siswa terlihat kurang berminat mengikuti pembelajaran Bahasa dan Sastra Indonesia dengan materi menulis cerpen, sehingga siswa menjadi kurang antusias dalam mengikuti pembelajaran. Guru merasa sulit membangkitkan minat siswa. Siswa terlihat tidak menyukai pembelajaran menulis dan siswa mengalami ketakutan pada pembelajaran menulis. Hal itu dikarenakan banyak siswa yang tidak berbakat dalam menulis cerpen. Keberhasilan menulis cerpen pada pembelajaran pra tindakan juga bisa dikatakan jauh dari harapan. Banyak siswa yang belum memenuhi KKM. KKM pelajaran Bahasa dan Sastra Indonesia SDN Tanjung 3, Bendo, Magetan yaitu 70. Berdasarkan KKM tersebut, diketahui ada 10 siswa yang belum memenuhi KKM. Rata-rata kelas juga masih di bawah KKM yaitu 65,8. Melihat hasil yang kurang memuaskan dari pembelajaran menulis cerpen pada kelas VI SDN Tanjung 3, maka disusun rencana untuk meningkatkan kualitas proses dan hasil menulis cerpen dengan menggunakan media puisi dan pendekatan SAVI.

Pada siklus I, guru melakukan perubahan cara mengajar. Siswa diberi apersepsi yang menarik hingga mereka menjadi antusias. Guru juga membacakan puisi yang akan dijadikan siswa untuk media menulis cerpen dengan pendekatan SAVI yaitu belajar harus menggunakan keempat unsur somatis, auditori, visual, dan intelektual. Di mana siswa harus bergerak, mendengarkan, membaca, mengamati, dan berpikir kritis dalam pembelajaran. Keberhasilan menulis cerpen pada siklus I ini, juga mengalami peningkatan. Dimana pada pra tindakan siswa yang tidak tuntas ada 10 siswa, pada siklus I ada 2 siswa. Nilai rata-rata kelas juga mengalami peningkatan, yaitu 75,5.

Pada siklus II, dilakukan revisi dalam memberikan tindakan. Guru memberikan apersepsi yang lebih menarik. Puisi-puisi yang dibacakan 
guru diambil dari tema yang dekat dengan kehidupan anak-anak. Selain dibacakan, guru juga membagikan beberapa puisi dalam bentuk tertulis pada tiap kelompok. Tiap kelompok diberi beberapa puisi dengan tulisan yang menarik pada kertas berwarna warni. Hal tersebut mampu membuat siswa lebih antusias dalam mengikuti pembelajaran. Setiap kelompok mendiskusikan beberapa puisi tersebut. Setelah berdiskusi, setiap siswa memilih satu puisi yang mereka sukai. Puisi tersebut kemudian diidentifikasi lebih mendalam untuk mengetahui makna puisi. Kemudian siswa menulis cerpen berdasarkan puisi yang telah diidentifikasi.

Pada pembelajaran siklus II, siswa jadi lebih aktif dalam mengikuti pembelajaran. Kemampuan siswa juga mengalami peningkatan. Pada siklus II, tidak ada siswa yang tidak tuntas. Nilai siswa semuanya mencapai KKM. Nilai rata-rata siswa meningkat menjadi 82,8 . Hal tersebut menunjukkan bahwa media puisi dan pendekatan SAVI dapat meningkatkan kemampuan menulis cerpen siswa kelas VI SDN Tanjung 3, Bendo, Magetan.

\section{E. Kesimpulan dan Saran}

Pada proses pembelajaran sebelum dilaksanakan tindakan siklus I dan II, proses pembelajaran masih belum efektif.
Kelas masih gaduh dan siswa masih kurang antusias pada pembelajaran menulis cerpen. Setelah dilaksanakannya tindakan pembelajaran menulis cerpen dengan media puisi dan pendekatan SAVI pada siklus I sudah mengalami peningkatan. Kelas sudah tidak gaduh dan siswa lebih banyak yang antusias dalam mengikuti pembelajaran. Pada siklus II, proses pembelajaran sudah efektif. Keadaan kelas sudah tenang. Semua siswa sudah antusias dalam mengikuti pembelajaran menulis cerpen.

Hasil tes pembelajaran menulis cerpen pada tahap pra tindakan masih rendah. Siswa yang tidak tuntas lebih banyak dibandingkan siswa yang tuntas. Nilai rata-rata kelas 65,8. Pada siklus I, terjadi peningkatan yaitu nilai rata-rata kelas naik menjadi 75,5 , sedangkan siswa yang tidak tuntas hanya 2 anak. Pada siklus II, nilai rata-rata kelas menjadi 82,8 dan semua siswa mendapatkan nilai diatas KKM.

Berdasarkan simpulan, diketahui bahwa media puisi dan pendekatan SAVI dapat meningkatkan kemampuan menulis cerpen pada siswa kelas VI SDN Tanjung 3, Bendo, Magetan. Oleh karena itu, peneliti memberi saran kepada guru Bahasa dan Sastra Indonesia, siswa, dan peneliti selanjutnya. (1) Guru Bahasa dan Satra Indonesia, diharapkan dapat meningkatkan kemampuan menulis cerpen dengan menggunakan media puisi dan pendekatan SAVI. (2) Siswa, peneliti memberi saran kepada siswa untuk terus berlatih menulis cerpen. Siswa bisa sering membaca puisi 
kemudian mengamati dan mengubahnya menjadi cerpen. (3) Peneliti selanjutnya, disarankan agar terus mengembangkan media dan pendekatan pembelajaran agar lebih menarik dan mampu meningkatkan kemampuan menulis cerpen.

\section{Daftar Pustaka}

Aminudin. 2002. Pengantar Apresiasi Karya Sastra. Bandung: Algesindo.

Asul Wiyanto. 2005. Kesusastraan Sekolah. Jakarta: Grasindo

Burhan Nurgiyantoro. 2005. Teori Pengkajian Fiksi. Yogyakarta: Gadjah Mada University Press.

Henry Guntur Tarigan. 2008. Menulis Sebagai Suatu Keterampilan Berbahasa. Bandung: Angkasa.

Herman J. Waluyo. 2011. Pengkajian dan Apresiasi Prosa Fiksi. Surakarta: UNS Press

Jakob Sumardjo dan Saini K.M. 1994. Apresiasi Kesusastraan. Jakarta: Gramedia Pustaka Utama.

Kaswan Darmadi. 1996. Meningkatkan Kemempuan Menulis. Yogyakarta: Andi Offset.
Panuti Sudjiman. 1988. Memahami Cerita Rekaan. Jakarta: Pustaka Jaya

Ristri Wahyuni. 2014. Kitab Lengkap: Puisi, Prosa, dan Pantun Lama. Yogyakarta: Saufa

Slamet. 2008. Dasar-Dasar Keterampilan Berbahasa Indonesia. Surakarta: UNS Press.

Soenardi Bahri Djamarah dan Aswan Zain. 2006. Metode Belajar Mengajar. Jakarta: Rineka Cipta.

Stanton, Robert. 2007. Teori Fiksi. (Diterjemahkan Sugihastuti dan Rossi Abi Al Irsyad). Yogyakarta: Pustaka Pelajar.

Suyatno. 2009. Menjelajah Pembelajaran Inovatif. Sidoarjo: Masmedia Buana Pustaka

Wiyatmi. 2006. Pengantar Kajian Sastra. Yogyakarta: Pustaka. 